\title{
Nutrient Dynamics and Litter Decomposition in Leucaena leucocephala (Lam.) De Wit Plantation in the Nigerian Derived Savanna
}

\author{
A. O. Oladoye ${ }^{1 *}$, B. A. Ola-Adams ${ }^{1}$, M. O. Adedire ${ }^{1}$, and D. A. Agboola ${ }^{2}$ \\ ${ }^{1}$ Department of Forestry and Wildlife Management, University of Agriculture, P.M.B. 2240, Abeokuta, \\ Nigeria \\ ${ }^{2}$ Department of Biological Science, University of Agriculture, P.M.B. 2240, Abeokuta, Nigeria \\ *Corresponding author; E-mail: Segun11us@yahoo.com
}

\begin{abstract}
Nutrient contents and rate of litter decomposition were investigated in Leucaena leucocephala plantation in the University of Agriculture, Abeokuta, Ogun State, Nigeria. Litter bag technique was used to study the pattern and rate of litter decomposition and nutrient release of Leucaena leucocephala. Fifty grams of oven-dried leaf litter of the species was weighed into $0.2 \mathrm{~mm}$ mesh litter bag, $35 \mathrm{~cm} \times 25 \mathrm{~cm}$ in size, these bags were closed at all ends. Eighteen litter bags were used for the studies. The litter bags were numbered and placed on the field (above ground) on 26th April 2005. Three bags were retrieved randomly from the field at 20-day intervals for 120 days. The nutrient concentration in $L$. leucocephala followed the trend $\mathrm{N}>\mathrm{P}>\mathrm{Mg}>\mathrm{Ca}>\mathrm{K}>\mathrm{Na}$ for leaf litter and seed components. Nutrient concentration in twigs and pods ranked $\mathrm{N}>\mathrm{Mg}>\mathrm{P}>\mathrm{Ca}>\mathrm{K}>\mathrm{Na}$. Among all the litter components, leaf litter contributed more nutrients, especially nitrogen, than other litter components. High potassium concentration during the dry season was due to lack of rainfall to leach out the element. Lower magnesium content in leaf litter was due to chlorophyll decay. High N-flux reflected the quantity and quality of nitrogen in the soil. Mass loss was significantly correlated with calcium $(P<0.05)$. At 120 days, $80 \%$ of the litter had decomposed; this implies that decomposition rate was at $0.6 \%$ per day. A net immobilization of all the nutrient elements at 20 days was due to lack of rainfall to leach out the nutrients. High rate of decomposition at the early stage was due to less moisture content in the soil and high temperature. Litter decomposed more during the wet season than the dry season.
\end{abstract}

\section{Introduction}

Energy flow and nutrient cycling are essential for the functioning of an ecosystem. Litterfall is a fundamental process in nutrient cycling and it is the main means of transfer of organic matter and mineral elements from vegetation to the soil surface (Vitousek \& Sanford, 1986; Regina et al., 1999). The analysis of litter quality and quantity and its rate of decomposition is highly important for the understanding of energy flow, primary productivity and nutrient cycling in forest ecosystems. Quantification of the nutrient flux associated with litterfall is important to the understanding of ecosystems dynamics.

The maintenance of natural systems or soil fertility in tropical forest ecosystems is achieved by high and rapid circulation of nutrients through the fall and decomposition of litter. The decomposed litter is also the basis of many food chains in tropical forests and is a principal source of energy for the saprobiota of the forest floor and soil, where the trophic chain of detritus predominates (Spain, 1984; Ola-Adams \& Egunjobi, 1992; Oliveira \& Lacerola, 1993; Regina et al., 1999).

Decomposition is a key process in the control of nutrient cycling and formation of soil organic matter (Berg \& McClaugherty, 2002). Decomposition of leaf litter is also an integral and significant part of biochemical (i.e. intra system) nutrient cycling and food webs; this refers to both the physical and chemical breakdown of litter and the mineralization of nutrients (Boulton \& Boon, 1991; Terrell et al., 2001). Decomposition of plant material is an important component in the study of forest ecosystem because of its critical role in nutrient cycling. Plant production depends on the recycling of nutrients within the system; recycling depends on the decomposition of organic matter and release of the nutrients it contains (Temel, 2003). The study, therefore, focuses on the amount of nutrient contents in litter and the rate of decomposition in leaf litter of L. leucocephala. 
Study site

\section{Materials and methods}

The study area is Leucaena leucocephala plantation, University of Agriculture, Abeokuta. The site is on latitude $7^{\circ}$ and $7^{\circ} 58^{1} \mathrm{~N}$ and on longitude $3^{\circ} 2^{1}$ and $20^{\circ} 37^{1} \mathrm{E}$, and it is $600 \mathrm{~m}$ above sea level. The general topography of the site is undulating while local topography is upper mid-slope. Soil is under laid by the pre-cambian metamorphic rocks of the basement complex with bed rock consisting predominantly of granite gneisses, bounded biotite, horn blende gneisses, quartzite and quartz schists. The soil is a fertile sandy loam, very dark in colour at the top surface and greyish brown in the subsoil with occasional areas of loamy soil.

The area has a tropical climate with a bimodal distribution of rainfall. It lies within the humid lowland region (Keay, 1953) with two distinct seasons. The wet season lasts from April to October while the dry season extends from November to March. The mean annual rainfall is $1113.1 \mathrm{~mm}$. The bimodal distribution of rainfall has its peaks in July and September and a break in August. The mean monthly temperature varies from $22.74{ }^{\circ} \mathrm{C}$ in August to $36.32{ }^{\circ} \mathrm{C}$ in March. The relative humidity is high ranging from $75.52 \%$ in February to $88.15 \%$ in July (Aiboni, 2001).

\section{Nutrient analysis}

For the determination of cations, dry ashing of plant tissue techniques, as described by Wilde et al. (1972), were used. Quantities of $\mathrm{Na}$ and $\mathrm{K}$ were determined by flame photometry; Ca and $\mathrm{Mg}$ by atomic absorption spectrophotometry; P by colorimetry, and nitrogen by the Kjeldahl distillation method. (Brenner, 1965; Isaac \& Kerber, 1972). Concentrations were read on an autoanalyser (Brenner, 1965).

\section{Decomposition studies}

A leaf litter decomposition experiment was carried out for 16 weeks (112 days) period from April 26 to August 24, 2005. Leaf litter of L. leucocephala was used to determine decomposition because this plant organ represents substantial proportion $(50-80 \%)$ of the total above ground litter production in terms of biomass, and represents a major nutrient input because of its relatively high nutrient concentration (Moughalu et al., 1994) and, more so, leaves decompose faster than twigs and leaf petioles.

Litter bag technique (Anderson \& Swift, 1983; Swift \& Anderson, 1989) was used to study the pattern and rate of litter decomposition and nutrient release of $L$. leucocephala. Fifty grams of oven-dried leaf litter of L. leucocephala was weighed into a $0.2-\mathrm{mm}$ mesh litter bag, $35 \mathrm{~cm} \times 25 \mathrm{~cm}$ in size; these bags were closed at all ends. The mesh size was chosen to prevent the inflow of excess litter material into the weighted sample. Eighteen litter bags were used for the studies. The litter bags were numbered and placed on the field (above ground) on 26th April 2005.

Three bags were retrieved randomly from the field at 20-day intervals for 120 days. The bags were carefully removed and put into the polyethylene bag and taken to the laboratory. The contents were emptied and extraneous materials, such as soil, visible animals and fine roots were removed. The remaining sample was oven-dried at $100{ }^{\circ} \mathrm{C}$ to a constant weight to determine the final weight of the remaining sample and ground for chemical analysis. The ground samples were analysed for $\mathrm{P}, \mathrm{Mg}, \mathrm{Na}$, $\mathrm{Ca}, \mathrm{K}, \mathrm{N}$ and carbon.

A single exponential equation, according to Olson (1963) and Oohara \& Yoshida (1971), was used to calculate decomposition constant $(\mathrm{k})$, and rates of loss of nutrient as follows:

$$
\underline{\mathrm{x}}_{1}=\mathrm{e}^{-\mathrm{kt}}
$$

where $x_{0}=$ the original weight of litter

$x_{1}=$ the final weight of litter

$\mathrm{e}=$ the base of natural logarithm

$\mathrm{k}=$ decomposition constant

West African Journal of Applied Ecology - Volume 13 


$$
\mathrm{t}=\text { the time. }
$$

The final weight represents the mass remaining after decay, and, hence, from this the percent of initial mass remaining was calculated. The percent of initial mass remaining was plotted against time (days).

\section{Nutrient composition of litter}

\section{Results}

In all the litter components, the relative ranking of nutrient concentrations were in the order $\mathrm{N}>\mathrm{P}>\mathrm{Mg}>$ $\mathrm{Ca}>\mathrm{K}>\mathrm{Na}$ for leaf litter and seed components, and $\mathrm{N}>\mathrm{Mg}>\mathrm{P}>\mathrm{Ca}>\mathrm{K}>\mathrm{Na}$ twig and pod components. The flower component appeared to have an order different from the above mentioned categories, i.e. $\mathrm{K}>\mathrm{N}>\mathrm{P}>\mathrm{Mg}>\mathrm{Ca}>\mathrm{Na}$. Sodium concentration in all the components appeared to follow the same trend, i.e. all the components were low in Na concentration. However, $\mathrm{N}$ was in higher quantities in all the components.

Leaf litter had the highest concentration of $\mathrm{Ca}, \mathrm{Mg}$ and $\mathrm{P}$. The highest concentration of phosphorus was recorded for leaf, seed and pod during the raining season and for twig and flower in the dry season, Potassium was high in seed and flower in the dry season. Seed component tended to be high in nitrogen and phosphorus. There was a noticeable increase in $\mathrm{N}, \mathrm{P}$ and $\mathrm{K}$ in the flower component between November and February - a period of little or no rainfall.

There was little variation in the monthly concentrations of the nutrient element in leaf litter and other litter components. Potassium was evidently high during the dry month in almost all the litter components. Mean monthly rainfall was positively correlated $(P<0.05)$, with all the elements but significantly high with $\mathrm{Ca}$ in leaf litter and twig (Table1). Maximum temperature showed significant positive relationship with $\mathrm{Mg}$ and $\mathrm{Na}(P<0.01)$, but negatively correlated with $\mathrm{P}$. However, it significantly correlated with nitrogen $(P>0.05)$. In the twig, maximum temperature was significantly correlated with $\mathrm{Mg}$ and $\mathrm{Na}(P<$ 0.05 ) and negatively correlated with phosphorus (Table1).

The nutrient with the greatest proportion for all the litter components (Table 2) is nitrogen followed by phosphorus, magnesium, calcium, potassium, and sodium content was the least. Leaf litter contributed the highest amount of nutrient element followed by twig, and the least was flower; leaf litter accounted for $61 \%$ of the nutrient, returned to the forest floor (Table 2). Litter components returned the nutrient to the soil in the order $\mathrm{N}>\mathrm{P}>\mathrm{Mg}>\mathrm{Ca}>\mathrm{K}>\mathrm{Na}$. Leaf litter returned more of $\mathrm{N}, \mathrm{P}, \mathrm{Mg}, \mathrm{Ca}$ and $\mathrm{K}$. However, seed returned more $\mathrm{P}$ than flowers and pods. Twigs returned more of $\mathrm{Mg}$ and $\mathrm{Ca}$ after leaf litter. A similar result was observed in $\mathrm{Ca}$. Quantitatively, all the litter components tend to contribute more nutrient elements to the forest soil during the wet season than the dry season.

\section{Litter decomposition}

Loss in weight in decomposing leaf litter of Leucaena with days was rapid (Fig. 1). At 60 days, 50\% of the initial weight of leaf litter had decomposed. Between 100 and 120 days, only $1 \%$ of the remaining weight decomposed. At 120 days, $80 \%$ of the original weight had decomposed (Table 3). This implied that $0.3 \mathrm{~g}$ or $0.6 \%$ of the leaf litter decomposed daily. Mass loss was negatively correlated with $\mathrm{P}, \mathrm{Na}$ and $\mathrm{K}$, but significantly correlated with $\mathrm{Ca}(P<0.05)$. However, it partially correlated with $\mathrm{N}$ and $\mathrm{Mg}$ (Table 4). 


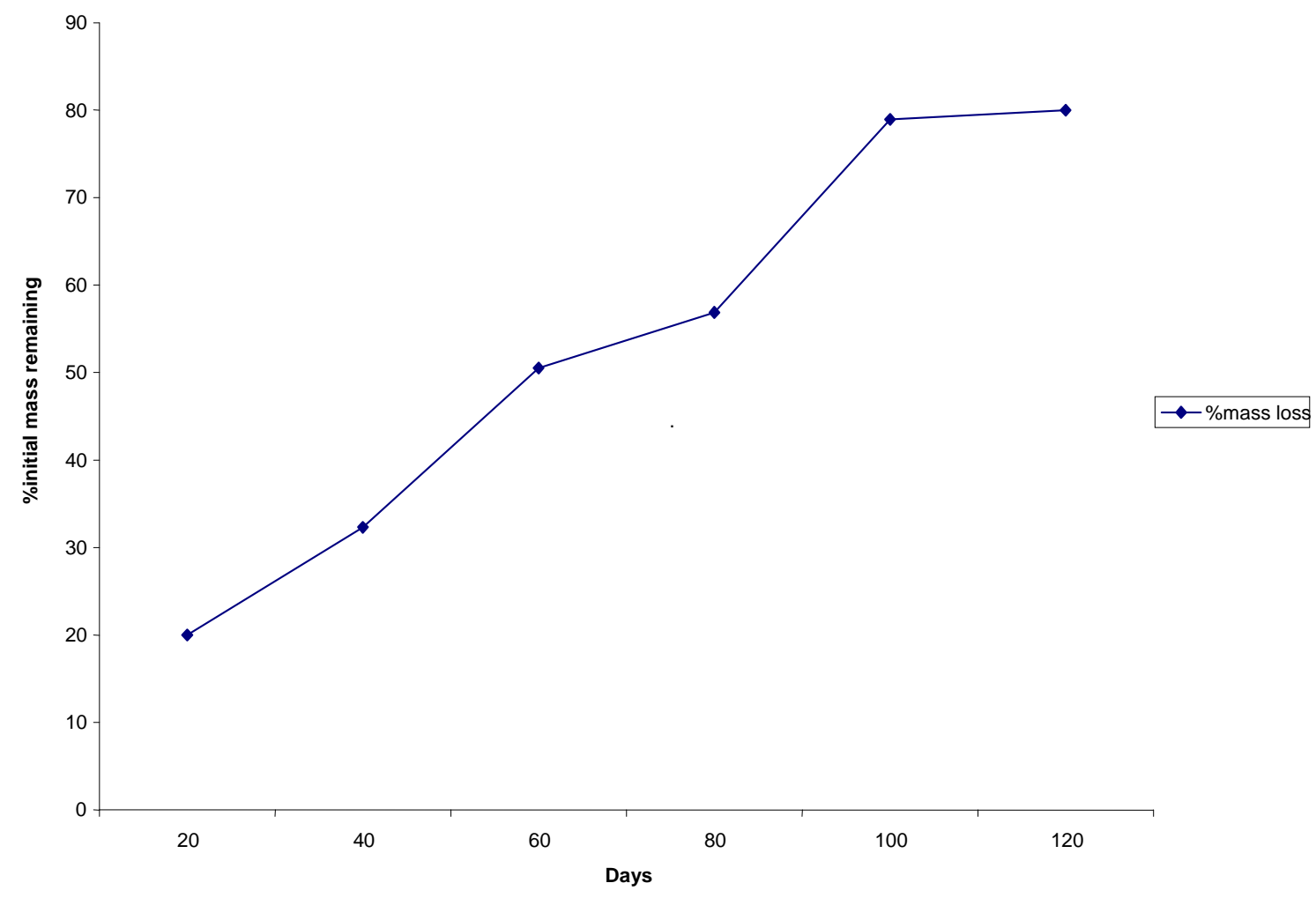

Fig. 1. Dynamics of \%mass loss in leaf litter decomposition

Generally, the loss in weight of decomposing leaf litter was linear and increased with days. The various mineral elements showed different pattern of decomposition. There was a noticeable increase in all the nutrient elements during decomposition. Phosphorus content decreased greatly within 40 days (Table 5), followed by a slow rate of decomposition. A noticeable increase was observed at 120 days for all the nutrient elements. Organic carbon remaining was higher than other nutrient elements at the end of the study. Nitrogen and organic carbon contents followed the same trend, with a gradual decrease up till the 60 th day, followed by a sudden increase in the 80th day.

Ca remaining after 20 days was lowest compared with other elements. A very rapid rate of decomposition was observed within the 40 days for $\mathrm{Ca}$, followed by a gradual increase in the $\mathrm{Ca}$ remaining. Potassium witnessed a diffuse pattern of mineralization. The nutrient element did not show any particular trend with increasing days. The trend of nutrient immobilization at 120 days was in the order $\mathrm{OC}>\mathrm{N}>\mathrm{Mg}>\mathrm{P}>\mathrm{Ca}>\mathrm{K}>\mathrm{Na}$.

TABLE 3

Pattern of Leaf litter decomposition

$\begin{array}{ccccccccc}\text { Days } & \text { Decomposition } & R_{l} / g & R_{2} / g & R_{3} / g & \text { Mean } / g & \% \text { Mass remain } & \% \text { Mass loss } & \begin{array}{c}\text { Mass } \\ \text { loss }\end{array} \\ 20 & \text { D1 } & 41.49 & 39.52 & 39.02 & 40.01 & 80.02 & 19.98 & 9.99\end{array}$

West African Journal of Applied Ecology - Volume 13 


$\begin{array}{rrrrrrrrr}40 & \text { D2 } & 35.72 & 32.21 & 33.58 & 33.84 & 67.68 & 32.32 & 16.16 \\ 60 & \text { D3 } & 24.24 & 25.24 & 24.76 & 24.74 & 49.48 & 50.52 & 25.16 \\ 80 & \text { D4 } & 21.84 & 20.78 & 22.05 & 21.56 & 43.12 & 56.88 & 28.44 \\ 100 & \text { D5 } & 10.27 & 10.77 & 10.54 & 10.52 & 21.04 & 78.96 & 38.48 \\ 120 & \text { D6 } & 10.57 & 9.84 & 10.05 & 10.01 & 20.02 & 79.98 & 39.99\end{array}$

R1, R2, R3 - Replicates.

TABLE 4

Correlations between mass loss in decomposition against nutrient content

$\begin{array}{ccccccc} & P & N a & K & C a & M g & N \\ \text { Mass loss } & -.554 & -.666 & -.260 & .864^{*} & .077 & .050\end{array}$

$* P<0.05$

TABLE 5

Percentage nutrient remaining in leaf litter after decomposition

\begin{tabular}{rrrrrrrr} 
Days & Decomposition & \multicolumn{1}{c}{$P \%$} & \multicolumn{1}{c}{ Na\% } & \multicolumn{1}{c}{$K \%$} & \multicolumn{1}{c}{ Ca\% } & \multicolumn{1}{c}{$M g \%$} & \multicolumn{1}{c}{$N \%$} \\
20 & & & & & & & \\
40 & D1 & 1095.9 & 1571.77 & 1037.76 & 64.02 & 1883.67 & 1569.02 \\
60 & D2 & 82.39 & 1208.57 & 475.87 & 1.35 & 1154.62 & 1280.6 \\
80 & D3 & 53.78 & 795.21 & 533.46 & 360.21 & 908.45 & 800.41 \\
100 & D4 & 32.81 & 754.60 & 330.13 & 337.74 & 977.09 & 740.22 \\
120 & D5 & 11.46 & 323.11 & 98.62 & 147.70 & 388.81 & 346.74 \\
& D6 & 89.57 & 328.90 & 258.07 & 174.57 & 482.08 & 453.39
\end{tabular}

\section{Discussion}

The concentration of plant nutrients in all the litter components of Leucaena litter followed this general trend: $\mathrm{N}>\mathrm{P}>\mathrm{Mg}>\mathrm{Ca}>\mathrm{K}>\mathrm{Na}$. However, leaf litter and seed component maintain that order, while twig and pod follow the order $\mathrm{N}>\mathrm{Mg}>\mathrm{P}>\mathrm{Ca}>\mathrm{K}>\mathrm{Na}$, and flower comes in a separate order, i.e. $\mathrm{K}>$ $\mathrm{N}>\mathrm{P}>\mathrm{Mg}>\mathrm{Ca}>\mathrm{Na}$. This suggests that $\mathrm{P}$ and $\mathrm{K}$ are concentrated in the reproductive structure (Reinaldo \& Philip, 1995). Variation in concentrations of nutrient elements reflected the seasonal trend in the amount of litter fall and the concentration of elements in the litter as observed by Muoghalu et al. (1993). Potassium, $\mathrm{P}$ and $\mathrm{Mg}$ had their maximum concentrations in the dry season although Klinge \& Rodrigues (1968) recorded a high concentration of $\mathrm{P}$ and $\mathrm{K}$ in litter in the wet season. The maximum concentration of these elements was in the dry season. High potassium content could be due to lack of rainfall during these months. Potassium is easily leached from leaves and litter by rain water (Egunjobi, 1971; Egunjobi \& Fasehun, 1972; Muoghalu et al., 1993). Lower content of highly mobile nitrogen might be due to leaching with rain water, and lower $\mathrm{Mg}$ content in leaf litter possibly reflected the chlorophyll decay which confirms findings by Kava'ova \& Acek (2003).

High calcium concentration in the litter components suggests that $\mathrm{Ca}$ is very active and immobile in the litter vascular system, and is believed to be recycled by means of litter decomposition (Kava'ova \& Acek (2003), and the Ca flux in the site may be due to quantity and quality of $\mathrm{Ca}$ in the soil. More nitrogen is returned through litter fall than any other element in this study, which was similarly observed by other studies (Muoghalu et al., 1993; Hermansah et al., 2002). Generally, tropical forests have higher concentration of nitrogen than comparable temperate forests due to higher concentra-tion of this element in leaf litter. It may be assumed that, because Leucaena is a leguminous plant, it is potentially capable of symbiotic fixation of atmospheric nitrogen, and supplies high levels of this element at this site. The higher concen-tration of $\mathrm{N}$ and $\mathrm{P}$ was comparable with the results obtained by Burghouts et al. (1993) and Hermansah et al. (2002).

West African Journal of Applied Ecology - Volume 13 
A significant positive correlation between mean monthly rainfall and $\mathrm{P}, \mathrm{K}, \mathrm{Mg}, \mathrm{Ca}$ and $\mathrm{N}$ in leaf litter and twig could be associated with leaching of these elements from litter and their differential retranslocation. Fluxes of nitrogen associated with leaf fall are an important component of the internal $\mathrm{N}$ cycle of a forest ecosystem. Reich et al. (1992) and Aerts (1996) suggest that they are determined largely by the physiological and anatomical characters of the main tree species. The concentration of plant nutrients in litterfall is important because it influences both the rate of decomposition and the amount of nutrient released to the soil during such decomposition. Therefore, the quality of litterfall, particularly $\mathrm{N}$, was probably affected by the concentration of $\mathrm{N}$ in the soil and also due to the nature of the tree which is a leguminous plant capable of fixing nitrogen.

The nutrient flux within the study site had nitrogen with highest flux and this may be presumably due to the tree species, a leguminous plant. Lower quantity of potassium may be due to leaching during the rainy season and also the greater number of days associated with wet season (Reinaldo \& Philip, 1995). The amount of nutrient flux corresponded with the dry weight of litter produced. Nwoboshi (1981) made a com-parison of the nutrient contents in the foliage and the litter, and suggested that not all the elements taken up by the foliar component of the shoot returned to the forest floor through litter fall.

Decomposition essentially results in a change of state of a resource under the influence of a number of biological and abiotic factors. Mass loss of resource has been regarded as the simplest expression of state of change. Leaf litter decomposition is an important aspect in mineral cycling as it determines the rate at which nutrients in the litter become available for recycling as well as store of inorganic elements still remaining in the litter component. Decomposition rate in this study was increasing with days. This could mean that different species have different rates of decomposition as reported by Muoghalu et al. (1994) and Temel (2003).

High rate of decomposition recorded at the early stage and around July and August may be attributed to less moisture content in the soil, leading to high aeration, causing the aerobic organism to be active. Frioretto et al. (1998) suggested that microbial activity could be limited by litter moisture content. This is in support of the hypothesis that climate set the general limits of the litter decomposition process through physiological constraints on the activity of organisms. The general conclusion is that physical climate determines rates of decay (Courteaux et al., 1995; Temel, 2003). The result showed a small percentage of original weight remaining; this may suggest that there was always litter remaining before new litter fall, a situation that favours erosion control in plantations.

Slow decomposition rate recorded at 120 days may indicate period of low rainfall. However, decomposition still occurs in dry season. High rate of decomposition recorded in April could be attributed to high temperature and moisture. High tempera-tures tend to increase microbial activity, which, in turn, leads to increased decom-position. It has been found that species with high nitrogen content decompose more rapidly than species low in nitrogen (Muoghalu et al., 1994; Hobbie, 1996; Vanlauwe et al., 1997). Slow rate of decomposition recorded between 100 and 120 days of the study was associated with period of low rainfall and low temperature. This further suggests that decomposition occurs faster during the rainy season than dry season.

Percentage mass remaining was lower; this was expected because of the initial substrate quality of Leucaena. Studies had suggested that nitrogen exerts great influence in the early stage of decomposition because it affects the physiological adaptation of decomposition organisms (Salamanca et al., 1995; Hobbie, 1996; Temel, 2003). Concentration of soluble and recalcitrant compounds influenced the rate of decomposition because different fractions of chemical compound present in leaf litter occur at different rates and are influenced by changes in microclimate. Hence the effect of time on the level of residue remaining at sampling.

A noticeable increase in all the nutrient concentration at the early stages of decomposition may be due to (1) the activity of microorganism who fed, died and decomposed on the litter, thus, increasing the nutrient content, and (2) period of low rainfall where leaching away of the nutrient was affected. Leaching is a biotic process whereby soluble matter is removed from the resource by the action of water. This is in West African Journal of Applied Ecology - Volume 13 
accordance with the observation by Frioretto et al. (1998) that microbial activity can be limited by litter moisture content. However, where there is high concentration of aerobic organism, nutrient release through decomposition will still continue because these organisms are active when there is high aeration.

The result indicated higher rate of $\mathrm{P}, \mathrm{K}$ and $\mathrm{Na}$ release. Similar trend has been observed by Singh (1980) and Adejuyigbe (2000) in the humid tropical forest. This rapid release could be attributed to the rapid loss of water soluble compounds. Potassium and phosphorus are usually constituents of metabolites enzymes system of the plant sap. Calcium and Mg are constituents of the structural make-up, such as the cell wall.

Early immobilization of $\mathrm{N}$ and $\mathrm{P}$ and subsequent decrease in concentration following mass loss have been found in other studies (Sharma \& Ambasht, 1987; Palm \& Sanchez, 1990; Lisanework \& Michelsen, 1994). The nutrient accumulation could also be from falling litter, herbivore frass, precipitation, through fall, stem flow, the soil substrate, and from in growth of fungal hyphae (Swift et al., 1979). High rate of nitrogen release from the leaf litter of Leucaena could be attributed to the influence of soil microarthropods. The sudden increase in nutrient remains at the end of the studies for nitrogen could indicate that soil $\mathrm{N}$ was being immobilized by the decomposing organism (Alfred \& O'sullivan, 2001). This suggests that mineralization of nitrogen was in two patterns: (1) Initial net mobilization followed by net mineralization in later stages and (2) Net mineralization with time.

Net accumulation for $\mathrm{P}$ and $\mathrm{K}$ could be attributed to the effect of environmental factors. Generally, the net accumulation of nutrient remaining at the end of the study may also suggest that some microorganisms acting on the resource, fed, died and decomposed on the litter, thus, increasing the nutrient quality. Sodium accumulation at the early stage of decomposition could be attributed to sodium input from rain, dust and to some lag in the release from litter (Muoghalu et al., 1994).

In decomposing litter, the chemical component may be regarded in a certain sequence, reflecting a succession of micro-organisms with different saprotrophic abilities (McClaugherty \& Berg, 1987; Temel, 2003). This means that the heterogenous group of microorganisms that invades the litter initially decomposes the water soluble in the non-matrixed part of the cellulose and hemicellulose (as energy sources), and finally the complex of interwoven holocellulose and lignin is attacked by cellulolytic and lignolytic fungi. Frankland (1992), Adejuyigbe (2000) and Cox et al. (2001) attributed litter decomposition and release of $\mathrm{N}, \mathrm{P}, \mathrm{K}, \mathrm{Ca}$ and $\mathrm{Mg}$ to the influence of microarthropods and earthworms. Decomposition is important because plant production depends on the recycling of nutrients within the system; recycling depends on the decomposition of organic matter and release of the nutrient it contains. It has long been recognized that soil fauna affects decomposition mainly through the combination of substrates, and influencing microbial activity (Tian et al., 1998).

The results agree with other authors' conclusion that litter decomposition rate is more related to litter quality than to environmental conditions (Facelli \& Pickett, 1991; De Santo et al., 1993; Muoghalu et al., 1994; Scott \& Binkley, 1997; Temel, 2003). C/N ratio followed the same trend with nitrogen. However, $\mathrm{C} / \mathrm{N}$ ratio could not satisfactorily describe the effect of litter quality on decomposition (Thorburn et al., 2001).

\section{References}

Adejuyigbe C. O. (2000). Effects of fallow legumes on soil micro arthropods and their roles in nutrient turnover under humid tropical conditions. (PhD Thesis.) University of Ibadan, Ibadan, Nigeria.

Aerts R. (1996). Nutrient resorption from senescing leaves of perennials; are there general patterns? J. Ecol. 84: 597-608.

Aiboni V. U. (2001). Characteristics and classification of soil of a representative topographical location in University of Agriculture, Abeokuta. Asset Series A 1(1): 51-61.

Alfred E. H. and O'Sullivans J. N. O. (2001). Leaf litter decomposition of Piper aduncum, Gliricidia sepium and Imperata cylindrical in the humid lowland of Papau New Guinea. Pl. Soil 230: 115-124.

Anderson J. M. and Swift M. J. (1983). Decomposition in tropical forest. In Tropical rainforest. Ecology and management. (S. L. Sutton, T. C. Whitmore and A.C. Chadwick, ed.), pp.287-309. Blackwell, Oxford.

Berge B. and McClaugherty (2002). Plant litter decomposition humus. Springer-verlag, New York.

Black C. A (ed.) (1965). Methods of soil analysis. Agronomy No. 9, Part 2. America Society of Agronomy, Madison, Wisconsin.

Boulton A. J. and Boon P. L. (1991). A review of methodology used to measure leaf litter decomposition in lotic environment. Time to turn over an old leaf? Aust. J. mar. Freshwat. Res. 42: 1-45.

West African Journal of Applied Ecology - Volume 13 
Burghouts T. B. A., Van Straalen and Bruignzeel L. A. (1993). Spatial heterogeneity of element and litter turnover in a Bornean rown forest. J. Trop. Ecol. 14: 477-506.

Brenner J. M. (1965). Total Nitrogen. In Methods of soil analysis (C.A. Black, ed.) Part 2, America society of Anatomy, Medison.

Courteaux M. M., Bottner P. and Berg B. (1995). Litter decomposition, climate and litter quality trend. Ecol. Evol. 10: 63-66.

Cox P., Wilkinson P. M. and Anderson J. M. (2001). Effects of fungal inocula on the decomposition of lignin and structural polysaccharides in Pinus sylvestris litter. Biol. Fert. Soils 33: 246-251.

De Santo A. V., Berg B., Rutigiliano F. A., Aleani A. and Frioretto A. (1993). Factors regulating early stage of decomposition of needle litters in five different coniferous forests. Soil Biol. Biochem. 25: 1423-1433.

Egunjobi J. K. (1971). Ecosystems processes in a stand of Ulex europaeus L. (11) recycling of chemical elements in the ecosystem. J. Ecol. 59 669-678.

Egunjobi J. K. and Fasheun F. E. (1972). Preliminary observations on the monthly litterfall and nutrient content of Pinus caribea leaf litter. Niger. J. Sci. 6(1).

Facelli J. M. and Pickett S. T. A. (1991). Plant litter - its dynamics and effects on plant community structure. Bot. Rev. 57: 133.

Frankland J. C. (1992). Mechanisms in fungal succession. In The fugal community: Its organization and role in the ecosystems, 2nd edn. (G. C. Carroll and D. T Wicklow ed.), pp. 383-401. Marcel Dekker, New York.

Frioretto A., Musacchio G. Andolfi and De Santo A. V. (1998). Decomposition dynamics of litters of various pine species in a Corsican pine forest. Soil Biol. Biochem. 30: 721-727.

Hermansah A. Z., Tsugiyuki M. and Toshiyuki. W. (2002). Litter fall and nutrient flux in tropical rain forest. West Sumatra, Indonesia 17th WCSS, 14-21 Aug. 2002. Thailand. Symposium No. 1125. Paper No. 1125.

Hobbie S. E. (1996). Temperate and plant spp. control over litter decomposition in Alaska tundra. Ecol. Monog. 66: 503-522 (ISI).

Isaac R. A. and Kerber J. D. (1972). Atomic absorption flame photometric techniques and uses in soil, plant and water analysis. In Instrumental methods for analysis of soil and plant tissues. (L. M. Walsh, ed.) Soil Science Society of America, Medison, Wilsconson.

Jackson M. C. (1962). Soil chemical analysis. Prentic Hall, New York.

Kava'ova M. and Acek S. V. (2003). Mountain Norway spruce forests. Needle supply and its nutrient content. J. For Sci. 49 (7): 327-332.

Keay R. W. J. (1953). An outline of Nigerian vegetation, 2nd edn. Government printer, Lagos, Nigeria.

Klinge H. and Rodrigue W. A. (1968a). Litter production in an area of Amazonian terra-firme forest. II. Mineral nutrient content of the litter. Amazoniana 1(4): 303-310.

Lisanework N. and Michelsen A. (1994). Litter fall and nutrient release by decomposition in three plantations compared with natural forest in the Ethiopian highland. For. Ecol. Mgmt 65:149-164.

McClaugherty C. and Berg B. (1987). Cellulose, lignin and nitrogen concentration as rate regulating factors in late stages of forest litter decomposition. Pedobiologia 30: 101-112.

Muoghalu J. I., Adeloye O. M. and Balogun R. T. (1994). Litter decomposition and inorganic element dynamics in a secondary rainforest at Ile-Ife. Nigeria. Afr. J. Ecol. 32: 208-221.

Muoghalu J. I., Akanni S. O. and Eretan O. O. (1993). Litter and nutrient dynamics in a Nigerian rainforest seven years after a ground fire. J. Veg. Sci. 4: 325-328.

Nwoboshi L. C. (1981). Nutrient cycling in managed teak plantation ecosystem. II. Litter fall and macro nutrient return to the forest floor. Niger. J. agric. Sci. 3(1): 9-14.

O'Connel (1988). Nutrient dynamics in decomposing litter in Karri (Eucalyptus diversicolor F. Muell) forests of South Western Australia. J. Ecol. 78: 1186-1203

Ola-Adams B. A. and Egunjobi J. K. (1992). Effects of spacing on litter fall and nutrient content in stands of Tectona grandis Linn. F. and Terminalia superba Engl. and Diels. Afr. J. Ecol. 30:18-32.

Oliveira R. and Lacerola L. D. (1993). Produ e compsiqu. Ca da serappilheira na Floresta da Tijula (Rz). Revta brasil Bot. 16: 93-99.

Olson J. S. (1963). Energy storage and the balance of producers and decomposers on ecological systems. Ecology 44:322-331.

Oohara H. N. and Yoshida N. K. (1971). Balance of producers and decomposers in a grassland system in Obihiro. J. Jap. Grassl. Sci. 17: 7-18.

Palm C. A. and Sanchez P. A. (1990). Decomposition and nutrient release patterns of the leaves of three tropical legumes. Biotropica 22: 330-338.

Regina M., Wetrington Braz Delitt and Vana stru FF aldi-De Vuono (1999). Litter and nutrient content in two Brazilian tropical Forest. Revta brasil. Bot. 22: 1999.

Reich P. B., Walter M. B. and Ellsworth D. S. (1992). Leaf life-span in relation to leaf, plant and stand characteristics among diverse ecosystems. Ecol. Monogr. 62: 365-392.

Reinaldo I. B. and Philip M. F. (1995). Carbon and nutrient flows in an Amazonian forest. Fine litter production and composition at Apiau. Roraima, Brazil.

West African Journal of Applied Ecology - Volume 13 
Salamanca E. F., Kaneko N., Katagiri S. and Nagayama Y. (1995). Effect of leaf litter mixtures on the decomposition of Pinus densiflora and Quercus serrata using field and laboratory microcosm methods. XXth International Union of Forestry Research Organisation (IUFRO) World Congress Tampere, Finland, Aug. 6-12, 1995.

Scott N. D. and Binkley D. (1997). Foliage litter quality and annual net N mineralization; Comparison across North America Forest sites. Oecoligia 111:151-159.

Sharma E. and Ambasht R. S. (1987). Litterfall, decomposition and nutrient release in an age sequence of Alnus nepalensis plantation in the Eastern Himalaya. J. Ecol.75: 997-1010.

Singh J. (1980). Studies on structural and functional aspects of two subtropical humid forest type in Meghalaya. (PhD Thesis.) North-Eastern Hill University, Shillong, India.

Spain A. V. (1984). Litter fall and the standing crop of litter in three tropical Australia rain forests. J. Ecol. 72: 947-961.

Swift M. J., Heal O. W. and Anderson J. M. (1979). Decomposition in terrestrial ecosystems. Blackwell, Stafford, UK. 372 pp.

Temel S. (2003). Litter decomposition of Picea orientalis, Pinus sylvestris and Castanea sativa trees crown in Artvin in relation to their iInitial title quality variables. Turkey Agric. For. 27: 23-243.

Swift M. J. and Anderson J. M. (1989). Decomposition. In Tropical Rainforest Ecosystems. Ecosystems of the World. (H. Lieth and M. S. A. Weryer, ed.), pp. 547-569. Elsevier, Amsterdam.

Terrell T., Baker I. J., Graeme Lockaby B., William H. C., Calvin E., Meier John S. A. and Marianne K. Berke (2001). Leaf litter decomposition and nutrient dynamics in four southern forested flood plain communities. Soil Soc. Am. J. 5: 1334 1347.

Thorburn P. J., Probert M. E. and Robertson F. A. (2001). Modelling decomposition of sugar cane surface residues with APSIM residue. Fld Crops Res. 70: 223-232.

Tian G., Adejuyigbe C. O., Adeoye G. O. and Kang B. T. (1998). Role of soil microarthropods in leaf decomposition and N release under various land-use practices in the humid tropics. Pedobiologia 42: 33-42.

Vanlauwe B., Diels J., Songinga N. and Merckx R. (1997). Residue quality and decomposition: an unsteady relationship. In Driven by native plant litter quality and decomposition. (G. Cadisch and K. E. Galler, ed.), pp. 157-166.

Vituosek P. and Sanfiord R. I. (1986). Nutrient cycling in moist tropical forest. A. Rev. Ecol. System.17: 1137-167. 